\title{
Curcuminoid-phospholipid complex induces apoptosis in mammary epithelial cells by STAT-3 signaling
}

\author{
Laura Starvaggi Cucuzza, Massimiliano Motta, \\ Silvia Miretti, Paolo Accornero and Mario Baratta ${ }^{1}$
}

Department of Veterinary Morphophysiology

Via Leonardo da Vinci 44

10095, Grugliasco 10095

University of Torino

Torino, Italy

${ }^{1}$ Corresponding author: Tel, 0039-0116709146;

Fax, 0039-0112369146; E-mail, mario.baratta@unito.it

DOI 10.3858/emm.2008.40.6.647

Accepted 4 August 2008

Abbreviations: RLU, relative light units; shRNA, small hairpin RNA

\begin{abstract}
Curcumin (from the rhizome of Curcuma longa) is well documented for its medicinal properties in Indian and Chinese systems of medicine where it is widely used for the treatment of several diseases. Epidemiological observations are suggestive that curcumin consumption may reduce the risk of some form of cancers and provide other protective biological effects in humans. These biological properties have been attributed to curcuminoids that have been widely studied for their anti-inflammatory, anti-angiogenic, antioxidant, wound healing and anti-cancer effects. In this study we have investigated on the effect of a curcumin phospholipid complex on mammary epithelial cell viability. HC11 and BME-UV cell lines, validated models to study biology of normal, not tumoral, mammary epithelial cells, were used to analyse these effects. We report that curcumin acts on STAT-3 signal pathway to reduce cell viability and increase apoptosis evaluated by the the amount of activated caspase 3 . Further it reduces MAPK and AKT activations. JSI-124, a STAT-3 inhibitor $(100 \mathrm{nM})$ was able to block the negative effect of curcumin on cell viability and caspase 3 activation. Finally the negative effect of cucumin on cell viability has been impaired in STAT-3 ${ }^{\text {i }}$ HC11, where STAT-3 protein was greatly reduced by shRNA-interference. These results indicate that curcumin presents a potential adverse effect to normal mammary epithelial cells and that it has a specific effect on signal trasduction in mammary epithelium.
\end{abstract}

Keywords: apoptosis; caspase 3; curcumin; mammary glands, human; STAT3 transcription factor

\section{Introduction}

Curcuma longa $L$. (Zingiberaceae family) rhizomes, has been widely used for centuries in indigenous medicine for the treatment of a variety of inflammatory conditions and other diseases (Maheshwari et al., 2006). These medicinal properties have been attributed mainly to curcuminoids, in particular to curcumin. Curcumin has been shown to possess a wide range of pharmacological qualities, including anti-inflammatory (Satoskar et al., 1986), anticancer (Kuttan et al., 1985), anti-oxidant (Toda et al., 1985), and wound healing properties (Sidhu et al., 1999). In vivo and in vitro studies have demonstrated curcumin's ability to inhibit carcinogenesis at three stages: tumor initiation, angiogenesis and tumor growth. Curcumin suppresses mitogen-induced proliferation of blood mononuclear cells, inhibits neutrophil activation and also prevents both serum-induced and PDGF-dependent mitogenesis of smooth muscle cells (Huang et al., 1992). Curcumin has also been reported to be a partial inhibitor of some protein kinases (Liu et al., 2004; Reddy et al., 2006). Recent reports also demonstrated the anti-tumor properties of curcumin in cancers of colon, forestomach and breast (Choudhuri et al., 2002).

Although the mechanisms underlying these diverse effects of curcumin are not fully understood multiple possibilities have been suggested, such as the inhibition of the NOS, the receptor tyrosine kinase and PKC activities (Korutla and Kumar 1994; Pan et al., 2000) and the alteration of transcriptional factors C-jun/AP-1 and nuclear factor UB and p53 (Singh and Aggarwal 1995; Jiang et al., 1996). Mechanisms that suppress tumorigenesis often involve modulation of signal transduction pathways, leading to alterations in gene expression, arrest of cell cycle progression or apoptosis. There is accumulating evidence that the efficiency of anti-tumor agents is related to the intrinsic propensity of the target tumor cells to respond to these agents by apoptosis (Cohen, 1993). Other evidence also shows that suppression of apoptosis by tumor- promoting agents in pre-neoplastic cells is thought to be an important mechanism in tumor 
promotion (Shibata et al., 1996). No data are available if these effects are related to tumor cells or if could be observed also in non-neoplastic cells and if the mechanism of action of curcumin induction of apoptosis may involved the physiological cascade of intracellular signals of transduction. Throughout mammary gland development several intracellular pathways play distinct roles during the growth (mammogenesis phase) and the differentiation (lactogenenesis phase) processes. In the present study, we examined the different effects of curcumin phospholipid complex (Curcuvet) that improves biodisponibility in tissues during mammary cell proliferation and differentiation and we addressed the relevance of STAT-3 in curcumininduced apoptosis on $\mathrm{HC} 11$ and BME-UV cell lines, two breast mammary non-tumorigenic cell lines.

\section{Materials and Methods}

\section{Materials}

Curcuvet, is a curcumin preparation (curcumin $13.02 \%$; demethoxyicurcumin $4.03 \%$; bis-demethoxycurcumin $2.95 \%$, total curcuminoids $20.0 \%+$ phospholipids $80 \%$ ) was kindly provided by Indena Spa (Milan, IT, www.indena.com). This product is a phospholipids complex of curcuminoids having improved bioavailability, as it has previously described for an analogous preparation for human medicine (Marczylo et al., 2007). Briefly, ground dry turmeric rhizomes $(1,000 \mathrm{~g})$ were defatted with hexane $(2,500 \mathrm{ml})$ before being extracted with ethanol-water 95:5 mixture $(7,500 \mathrm{ml})$. Curcuminoids were then crystallized by slowly adding hexane $(500 \mathrm{ml})$ to the hydroalcoholic solution and allowing the resulting mixture to stand for $24 \mathrm{~h}$. A microcrystalline orange solid was filtered and dried at $60^{\circ} \mathrm{C}$ under vacuum to yield $36.7 \mathrm{~g}$ of extract having a curcumin content of $71.74 \%$ and a total curcuminoid content of $93.8 \% \mathrm{w} / \mathrm{w}$. After that, a complex was prepared as follows: turmeric rhizomes extract having a total curcuminoid content of $93.8 \% \mathrm{w} / \mathrm{w}$ were dissolved in ethanol $(800 \mathrm{ml})$ and the solution was refluxed. $77.6 \mathrm{~g}$ of soy phospholipids were slowly added in portions, under reflux and with stirring. The resulting suspension was refluxed with stirring for $1 \mathrm{~h}$, then hot concentrated under reduced pressure and finally dried in oven. $97.6 \mathrm{~g}$ of an orange waxy product were obtained, having a curcumin content of $13.02 \%$ and a total curcuminoid content of $20.0 \% \mathrm{w} / \mathrm{w}$. HPLC titration was determined according to $\mathrm{He}$ et al. (1998).

The curcuminoids complex (CURC) with $93.8 \%$ of curcuminoids was dissolved in ethanol 1:1, (10 $\mathrm{mg} / \mathrm{ml}$ ), and that was diluted to the final concentration in RPMI $1640(1 \mu \mathrm{g} / \mathrm{ml})$. The residual ethanol at this working concentration was $0.01 \%$, control samples were treated with the same solvent percentage.

RPMI 1640, insulin, ovine recombinant prolactin, EGF, dexamethasone and Cucurbitacin I (JSI-124) were purchased from Sigma-Aldrich Inc. (St Louis, MO). iQ SYBR Green Supermix for Real Time PCR was purchased from Bio-Rad Laboratories Inc. (Hercules, CA). FCS, glutamine and penicillin were purchased from EuroClone Ltd. (West York, UK).

\section{Cell culture}

$\mathrm{HC} 11$ cell line was derived from midpregnant BALB/C mouse mammary tissue and is considered to retain important characteristics of normal mammary epithelial cells such as the ability to produce milk protein in response to lactogenic hormones without cultivation on exogenous extracellular matrix or cocultivation with adipocytes or fibroblasts (Marte et al.,1995). HC11 cells were maintained in RPMI 1640 medium containing 10\% FCS, $5 \mu \mathrm{g} / \mathrm{ml}$ insulin, $10 \mathrm{ng} / \mathrm{ml}$ EGF, $2 \mathrm{mM}$ L-glutamine, 50 units/ml penicillin and $50 \mu \mathrm{g} / \mathrm{ml}$ streptomycin (growth medium). To induce differentiation, cells were grown to confluence and cultured for an additional day in growth medium. Subsequently, the cells were incubated for up to 4 days in differentiation medium [RPMI 1640 medium containing $3 \%$ FCS and the lactogenic hormones dexamethasone $(1 \mu \mathrm{M})$, insulin (5 $\mu \mathrm{g} / \mathrm{ml})$ and prolactin $(5 \mu \mathrm{g} / \mathrm{ml})]$. Differentiation was monitored by measuring expression of the milk protein $\beta$-casein (Baratta et al., 2000).

The BME-UV bovine mammary epithelial cell line was kindly provided by Dr. Politis (Agricultural University of Athens, Athens, Greece). The BMEUV cell line derives from primary epithelial cells of lactating Holstein Frison. This cell line is the only known bovine mammary epithelial cell line responsive to EGF and represent a valid model system to examine bovine mammary epithelial proliferation and differentiation and cell-to-cell communication. BME-UV cells were maintained in DMEM supplemented with $10 \%$ FCS.

\section{Cell viability}

Cell viability was evaluated using WST-1 assay (Roche Diagnostic, Penzberg, Germany). The intensity of the coloured compound formed (formazan dye) was quantified with an ELISA microplate reader (Biorad 680). Briefly, 300 cells/well were seeded in a 96-wells microplate. After $12 \mathrm{~h}$ of 
culture, control cells $(n=6)$ were quantified by WST-1 reagent (day 0 ) to normalize the successive measurements of treated and not-treated groups. When WST-1 reagent was added the wells were subjected to further incubation for a period of 60 min to facilitate the reaction between mitochondrial dehydrogenase released from viable cells and tetrazolium salt of WST-1 reagent. The absorbance was measured at $450 \mathrm{~nm}$, with the reference at $620 \mathrm{~nm}$. Cell viability was routinely evaluated at 24, 48 and $72 \mathrm{~h}$ after the treatments.

\section{Western blot analysis}

Cells were lysed with EB buffer $(10 \mathrm{mM}$ Tris $\mathrm{pH}$ 7.4, $150 \mathrm{mM} \mathrm{NaCl}, 5 \mathrm{mM}$ EDTA, 10\% glycerol, 1\% Triton X-100) supplemented with Protease Inhibitor Cocktail (Sigma), $1 \mathrm{mM}$ PMSF and $1 \mathrm{mM}$ sodium orthovanadate. The protein concentration was determined using the BioRad Dc Protein Assay (Bio-Rad Laboratories Inc.). Twenty micrograms of total protein were run on $10 \%$ SDS-PAGE and transferred to Hybond-C extra nitrocellulose membranes (GE Healthcare Life Sciences, Piscataway, NJ). Bound antibodies were detected using HRP-conjugated secondary antibodies and Supersignal ECL (Pierce, Rockford, IL) and recorded by $X$-ray film. Antibodies were obtained as follows: phospho STAT-3, STAT-3, phospho STAT-5, phospho Akt, MAPK, cleaved caspase-3 (Cell Signaling Technology, Danvers, MA); STAT-5, Akt, (Santa Cruz Biotechnology, Santa Cruz, CA); $\alpha$-tubulin, phospho- MAPK (Sigma-Aldrich, St. Louis, MO). The detected bands on the X-ray films were quantified using densitometry software (ChemiDoc, Bio-Rad Laboratories Inc.).

\section{$\beta$-casein gene expression measurement by real time PCR}

Cells were lysed and total RNA was extracted with Macherey-Nagel NucleoSpin RNA II, (Düren, Germany) following the manufacturer's instructions. One microgram of total RNA was reverse transcribed with iScript cDNA kit (Bio-Rad Laboratories Inc.) following the manufacturer's instructions. Diluted cDNAs (1:5 and 1:50) were used for Real Time PCR amplification. Primers for mouse $\beta$-casein were: forward 5'TCACTCCAGCATCCAGTCACA3', reverse 5'GGCCCAAGAGATGGCACCA3'; primers for $18 \mathrm{~S}$ (reference gene) were: forward $5^{\prime} \mathrm{C}$ GTTTGTGTGGGGAGTGAATGGTG3', reverse 5'GCGTGGGGGTTGGCGGAAAGAGAA3'. Real time PCR parameters were: cycle $1,95^{\circ} \mathrm{C}$ for $90 \mathrm{~s}$; cycle $2,95^{\circ} \mathrm{C} 60 \mathrm{~s}, 59^{\circ} \mathrm{C} 20 \mathrm{~s}$ for 40 cycles. The 2- $\triangle \triangle C T$ method was used to analyze the data as described by (Livak and Schmittgen 2001).

\section{Quantitative analysis of caspase 3 activity}

This procedure has been published by Hermisson et al. (2000). Briefly, the cells were seeded in 96-well plates $\left(1 \times 10^{4}\right.$ cells per well) and allowed to grow for $24 \mathrm{~h}$. The cells were treated with curcuma extract for $48 \mathrm{~h}$ and lysed in lysis buffer containing $25 \mathrm{mM}$ TRIS- $\mathrm{HCl}(\mathrm{pH} 8.0), 60 \mathrm{mM}$ $\mathrm{NaCl}, 2.5 \mathrm{mM}$ EDTA and $0.25 \% \mathrm{NP} 40$ for $10 \mathrm{~min}$. The Caspase-3 Substrate II, Fluorogenic Ac-DEVDamc (12.5 $\mu \mathrm{M}$, Merck Chemicals Ltd., Beeston Nottingham, UK), diluted in PBS, was added and incubated at $37^{\circ} \mathrm{C}$ for $10 \mathrm{~min}$. Caspase activity was measured for $1 \mathrm{~h}$ using a CytoFluor 2350 Millipore fluorimeter at $360 \mathrm{~nm}$ excitation and $480 \mathrm{~nm}$ emission wave lengths. Data are expressed as RLU (relative light units) and are the mean of 10 replicates for each treatments.

\section{Inhibition of STAT-3 pathway}

$\mathrm{HC} 11$ cell line was quiescent for $12 \mathrm{~h}$ in serumdepleted media. Cucurbitacin I (JSI-124) a novel selective inhibitor of Jak 2/STAT 3 signaling (Blaskovich et al., 2003) was used to block STAT-3 phosporilation. JSI-124 was dissolved in DMSO and diluted in serum-free media prior to addition 1 $\mathrm{h}$ before treatments. Cells were stimulated for 30 min with CURC (100 ng/ml) or IL-6 (100 ng/ml), used as positive control.

\section{STAT-3 inhibitor effect on caspase 3 activity}

CURC effect on caspase activity was measured by Caspase-3 Substrate II fluorogenic reaction in HC11 cell line treated with. Briefly, JSI-124 was dissolved in DMSO and serially diluted in serumfree media prior to addition $1 \mathrm{~h}$ before CURC treatment to HC11 cells. Data were normalized on the control (not starved cell). Positive control was performed by a UV-treatment $(10 \mathrm{~min})$ for $4 \mathrm{~h}$. A significant dose-dependent effect was observed only at $100 \mathrm{ng} / \mathrm{ml}$. Data are expressed as mean \pm SEM of 10 replicates, repeated three times. Asterisks mean $P<0.05$

\section{STAT-3 inhibitor effect on cell viability}

HC11 cell line was quiescent for $12 \mathrm{~h}$ in serumdepleted media. JSI-124 (10 or $100 \mathrm{nM}$ ) were dissolved in DMSO and added to CURC treatment $(100 \mathrm{ng} / \mathrm{ml})$ for $24 \mathrm{~h}$. Viability was measured by WST-1 test. Data are expressed as percentage on internal control for each cell type measured after 
$12 \mathrm{~h}$ after cell seeding (time 0 ) and are mean \pm SEM of 8 replicated repeated in three independent experiments. Asterisks mean $P<0.05$

\section{Lentiviral vectors for expression of small hairpin RNAs}

Vectors for stable shRNA-mediated gene inactivation were created by cloning duplex small hairpin RNA (shRNA) oligos against STAT-3 (shSTAT-3) (Follenzi et al., 2000; Chatterjee et al., 2004) or control oligos (TM2) (Taulli et al., 2005) into pSUPER vector (OligoEngine). Lentiviral constructs were generated by subcloning the $\mathrm{H} 1$-promotershSTAT-3/TM2 cassette from the derived vectors into the EcoRV-Xhol sites of the PCCL.sin.PPT. hPGK.GFPWpre lentiviral vector (Follenzi et al., 2000).

\section{Production of lentiviruses}

High titer lentiviruses were obtained by calcium phosphate-mediated co-transfection of 293T cells with the modified pCCL.sin.PPT.hPGK.GFPWpre transfer vectors and the packaging vectors PMDLg/ pRRE, pRSV-Rev and pMD2.VSVG. Supernatants were harvested after $30 \mathrm{~h}$, filtered through $0.22 \mu \mathrm{m}$ pore size filters (Millipore) and concentrated by ultracentrifugation $(50,000 \times \mathrm{g}$ for $2 \mathrm{~h})$.

\section{Transduction of $\mathrm{HC} 11$ cells}

HC11 cells $\left(1 \times 10^{5}\right.$ in $35 \mathrm{~mm}$ diameter culture dishes) were incubated with viruses in the pre- sence of $8 \mu \mathrm{g} / \mathrm{ml}$ polybrene for $24 \mathrm{~h}$. Infectivity was determined after $72 \mathrm{~h}$ by FACS analysis of EGFP positive cells. Sorting of GFP positive cells was performed on MoFlo Cell Sorter using Summit software (MoFlo, DakoCytomation Inc., Fort Collins, $\mathrm{CO})$. To maximize purification efficiency, the flow speed used during cell sorting corresponded to $(\sim 2$ $\times 10^{4}$ ) cells per second. The purity of cells in the sorted samples was routinely greater than $98 \%$.

\section{Statistical analysis}

Gene expression analysis and western blots were repeated three times independently. Cell proliferation test was performed three times and each treatment had six replicates. In proliferation analyses, data collected from HC11 cells or STAT3-HC11 cells were expressed in percentage relative to the internal control (optical density detected after the first $12 \mathrm{~h}$ of culture, day 0 ). Experimental data are presented as mean $\pm S D$. Statistical differences between treatments and interactions were calculated with multifactorial ANOVA using the Statgraphics package (STSC Inc., Rockville, MD). When significant differences were found, means were compared by Scheffé, F test.

\section{Results}

\section{Effect of CURC on cell viability}

Viability was reduced when EGF was depleted from the culture medium of HC11 proliferating cells
A

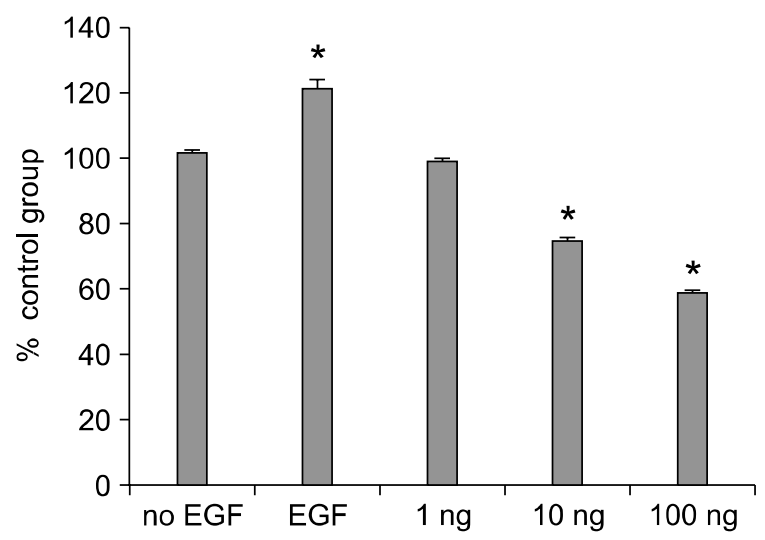

B

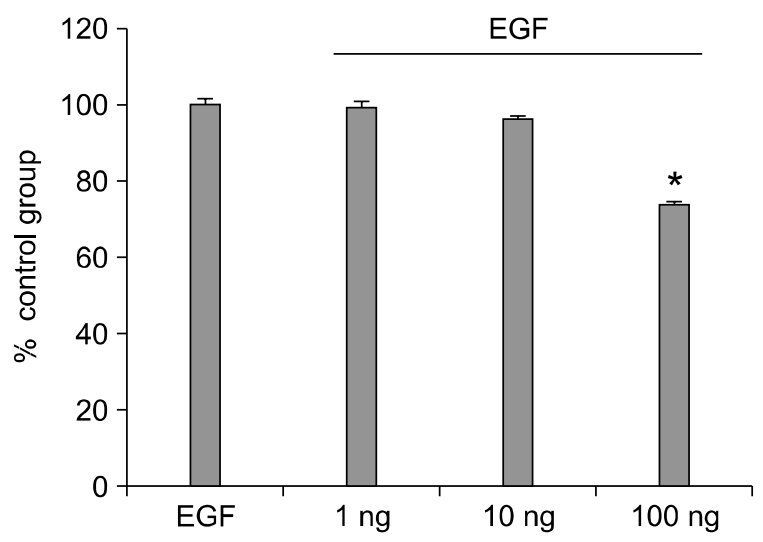

Figure 1. Effect of CURC on cell viability in HC11 cell line. Cells were treated with CURC (1-100 ng/ml) alone (A) or in association with EGF $(0.1 \mathrm{ng} / \mathrm{ml})$ (B) for $48 \mathrm{~h}$. Viability was measured by WST-1 test. Data are expressed as percentage on internal control for each cell type measured after $12 \mathrm{~h}$ after cell seeding (time 0 ) and are mean \pm SEM of 8 replicated repeated in three independent experiments. ${ }^{*}$ mean $P<0.05$. 
A

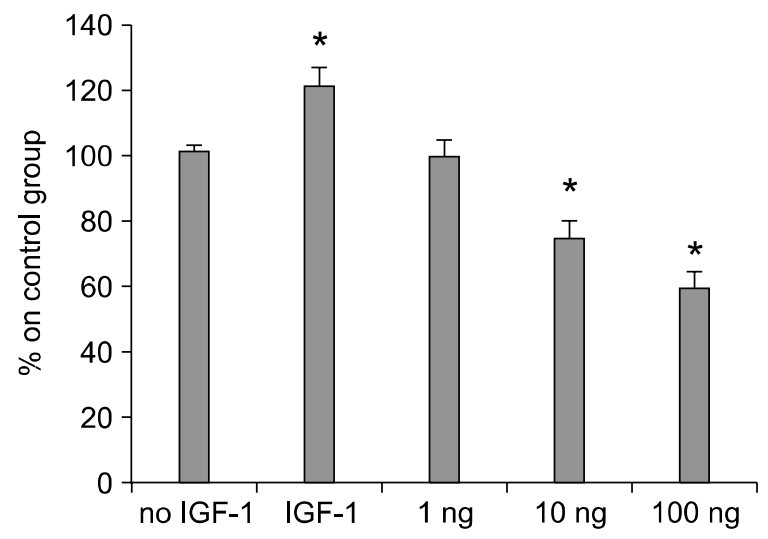

B

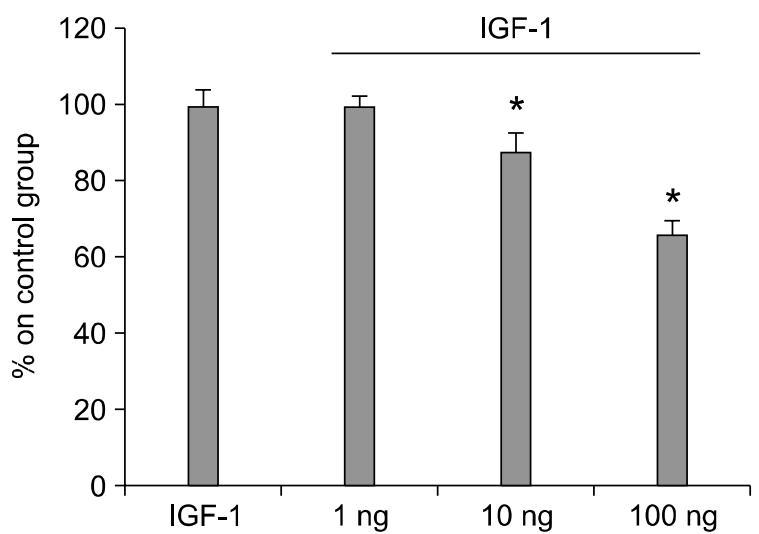

Figure 2. Effect of CURC on cell viability in BME-UV cell line. Cells were treated with CURC (1-100 ng/ml) alone (A) or in association with IGF-1 (1 ng/ml) (B) for $48 \mathrm{~h}$. Viability was measured by WST-1 test. Data are expressed as percentage on internal control for each cell type measured after $12 \mathrm{~h}$ after cell seeding (time 0 ) and are mean \pm SEM of 8 replicated repeated in three independent experiments. ${ }^{*}$ mean $P<0.05$.
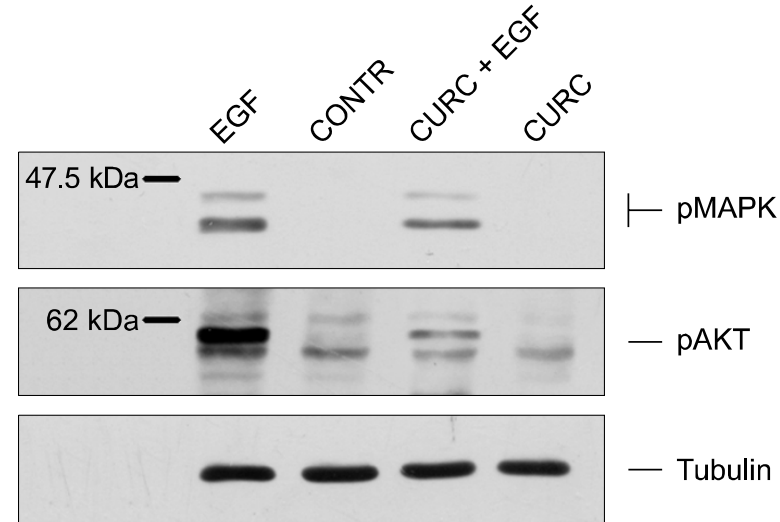

Figure 3. MAPK and AKT phosphorylation induced by EGF $(10 \mathrm{ng} / \mathrm{ml})$ and/or CURC in HC11 cell line assessed by Western blot. Cells are starved for $12 \mathrm{~h}$ in Medium 1640 without serum and growth factors.

$(P<0.05,>30 \%$ of reduction after $48 \mathrm{~h}$ of incubation). CURC reduced cells viability at $10 \mathrm{ng}$ and $100 \mathrm{ng} / \mathrm{ml}$ (up to 25 and $40 \%$, respectively, Figure $1 \mathrm{~A})$ when it was incubated without EGF but also it was observed to reduce cell viability in association with EGF $(0.1 \mathrm{ng} / \mathrm{ml})$ at 10 and $100 \mathrm{ng} / \mathrm{ml}$ (up to 5 and $25 \%$ of reduction compared to control, Figure 1B). The same effect was observed in BME-UV cell line where IGF-1 was used as positive control (Figure 2).

\section{Effects of CURC on MAPK and AKT activation}

EGF is known to activate downstream signaling via phosphorylation and activation of MAPK and Akt proteins. Therefore, we monitored the phospho-

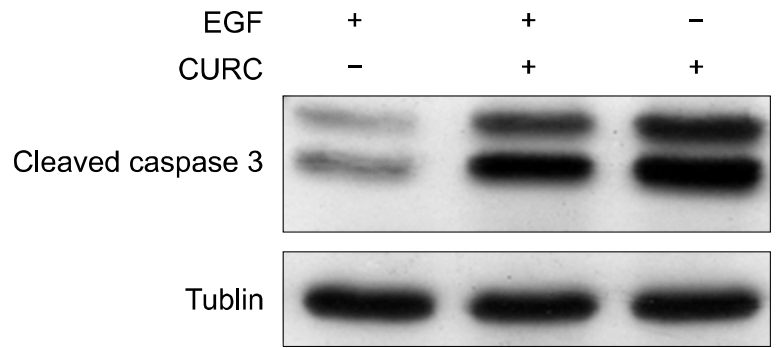

Figure 4. A representative experiment of cleaved caspase 3 assessed by Western blot: cells were incubated in medium RPMI 1640 3\% FCS containing $10 \mathrm{ng} / \mathrm{ml}$ insulin, with EGF (lane 1), an association of EGF plus CURC (100 $\mathrm{ng} / \mathrm{ml}$, lane 2$)$ and only CURC (100 $\mathrm{ng} / \mathrm{ml}$, lane 3$)$.

rylation state of MAPK and Akt in mammary cells stimulated for 15 min with EGF and CURC, alone or in combination (Figure 3). As expected, EGF induced MAPK and AKT phosphorylation. In contrast, CURC reduced $(P<0.05)$ MAPK and AKT phosphorylation when mediated by EGF.

\section{Effect of CURC on cleaved caspase 3}

Loss of viability induced by EGF deprivation may be a consequence of an induction of apoptosis. Apoptosis can be brought about by initiation of either the intrinsic or extrinsic pathways, both of which involve caspases (cysteine proteases) as key effectors. We measured if CURC treatment induced a loss of cell viability with the initiation of an apoptotic event. As Figure 4 showed, EGFdeprived $\mathrm{HC} 11$ cells increased significantly $(P<$ 0.01 ) cleaved caspase 3 signal compared to EGF treated cells (lanes 1 vs 2). We also measured the 
HC11

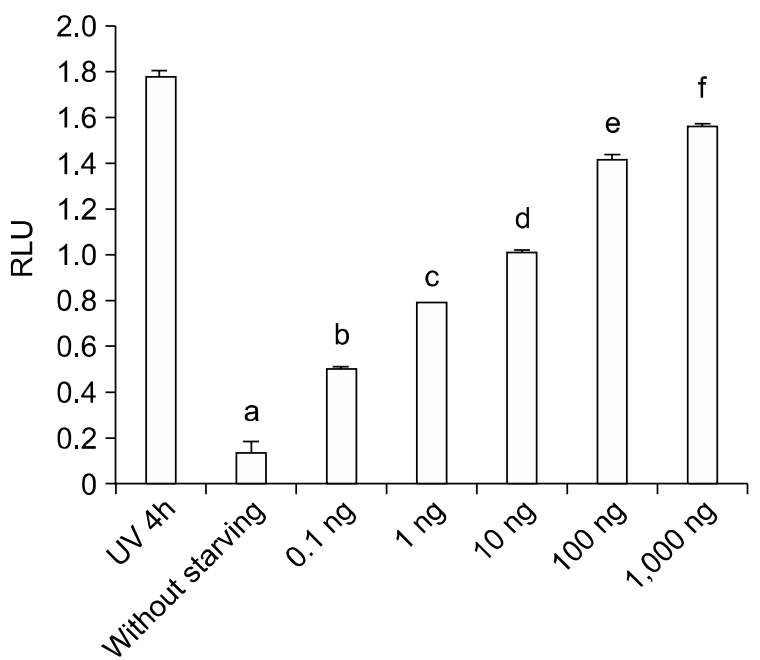

BME

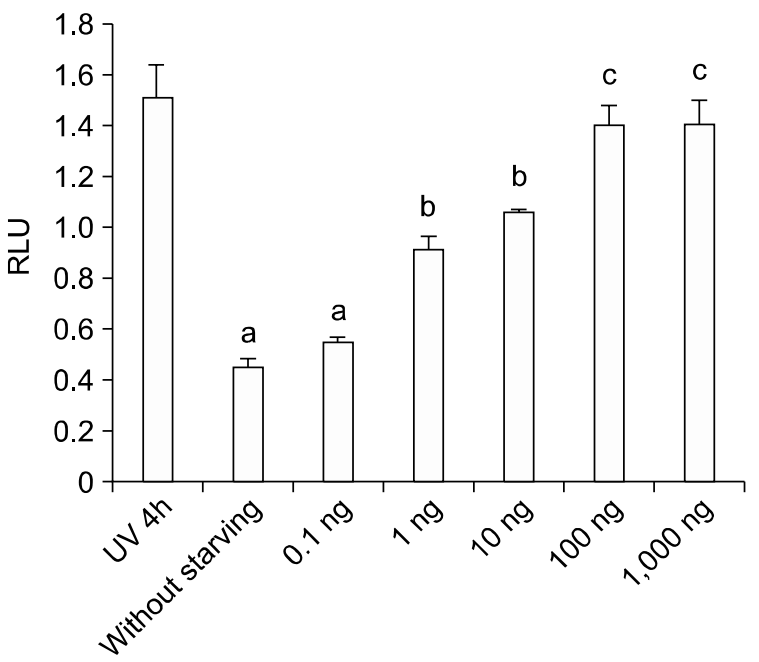

Figure 5. CURC effect on caspase activity measured by Caspase-3 Substrate II fluorogenic reaction. In both cell lines, (HC11 and BME-UV) the data were normalized on the control (not starved cell). Positive control was performed by a UV-treatment for $4 \mathrm{~h}$. A significant dose-dependent effect was observed from 0.1 to $100 \mathrm{ng} / \mathrm{ml}$. Data are expressed as mean \pm SEM of 10 replicates, repeated three times. Different letters mean at least $P<0.05$.

A

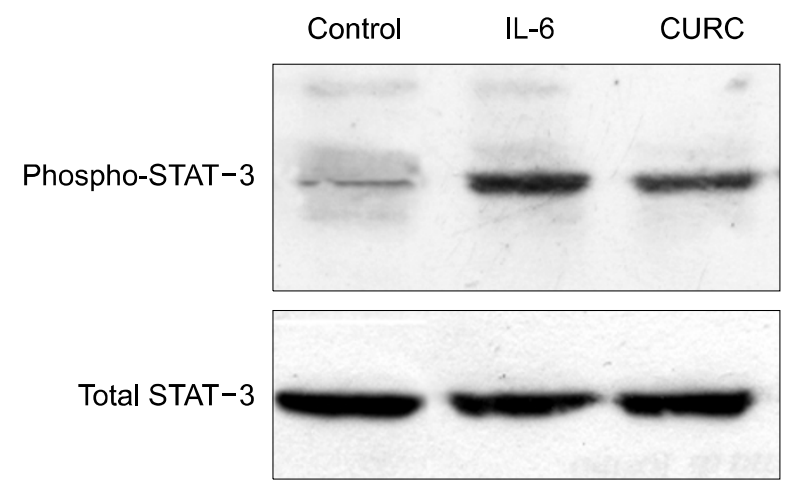

B

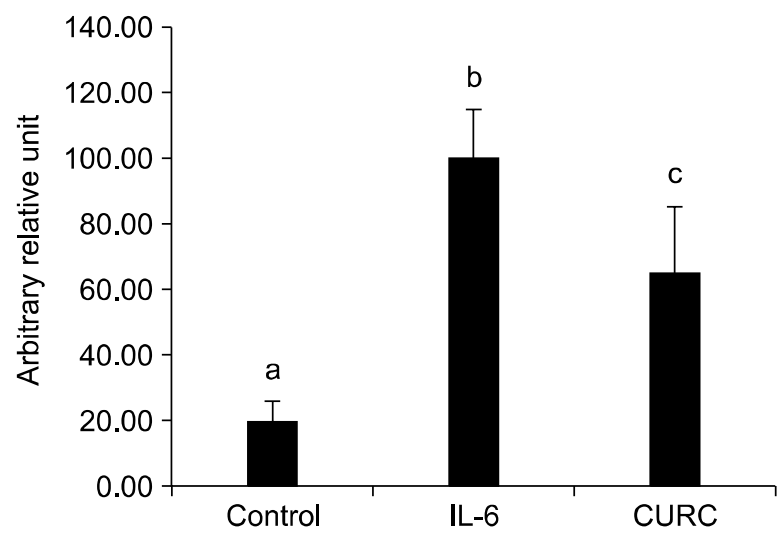

Figure 6. CURC enhances phosphorylation of STAT-3. A Western blot of phospo-STAT-3 activation. Cells were stimulated for 30 min in proliferation medium containing $10 \mathrm{ng} / \mathrm{ml} \mathrm{EGF,} 5 \mu \mathrm{g} / \mathrm{ml}$ insulin with CURC (100 ng/ml) or IL-6 (100 ng/ml), used as positive control; B densitometric analysis from data of three independent experiments. Each value represents the mean \pm SD. Different letters mean at least $P<0.05$.

quantitative affect of CURC on caspase-3 activity. CURC showed a dose-dependent effect on caspase 3 activity at very low doses $(10-1,000 \mathrm{ng} / \mathrm{ml})$ in both $\mathrm{HC} 11$ and BME cell lines (Figure 5).

\section{Effects of CURC on STAT-3 and STAT-5 activation}

PRL and IL-6 are known to activate downstream signaling via phosphorylation and activation of STAT-5 and STAT-3 proteins. Therefore, we monitored the phosphorylation state of STAT 5 and

\section{Control CURC PRL PRL +
CURC}

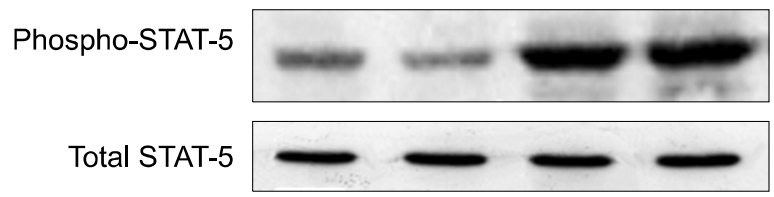

Figure 7. CURC does not activate STAT-5 in HC11 cells. Cells were stimulated for $20 \mathrm{~min}$ in differentiation medium containing $5 \mu \mathrm{g} / \mathrm{ml}$ prolactin or CURC $(100 \mathrm{ng} / \mathrm{ml})$, as indicated. Activation of STAT-5 was assessed by Western blotting using an anti-phospho STAT-5 antibody. 
STAT 3 in HC11 cells stimulated for 15 min with CURC. CURC was able to enhance STAT-3 phosphorylation $(P<0.05)$ (Figure 6$)$ but not statistical difference was observed in STAT-5 activation (Figure 7).

\section{Effect of CURC on $\beta$-casein gene expression in differentiating mammary epithelial cells}

Mammary epithelial cell line $\mathrm{HC} 11$ was able to differentiate and induce expression of the $\beta$-casein gene when stimulated with lactogenic hormones for $72 \mathrm{~h}$. As previously reported (Baratta et al., 2000) treatment of confluent cultures with differentiation medium containing the lactogenic hormones dexamethasone, insulin and prolactin led to a dose-dependent induction of $\beta$-casein mRNA expression, while proliferating cells or $\mathrm{HC} 11$ cultured in differentiation medium lacking prolactin expressed very low levels of $\beta$-casein mRNA. In con-

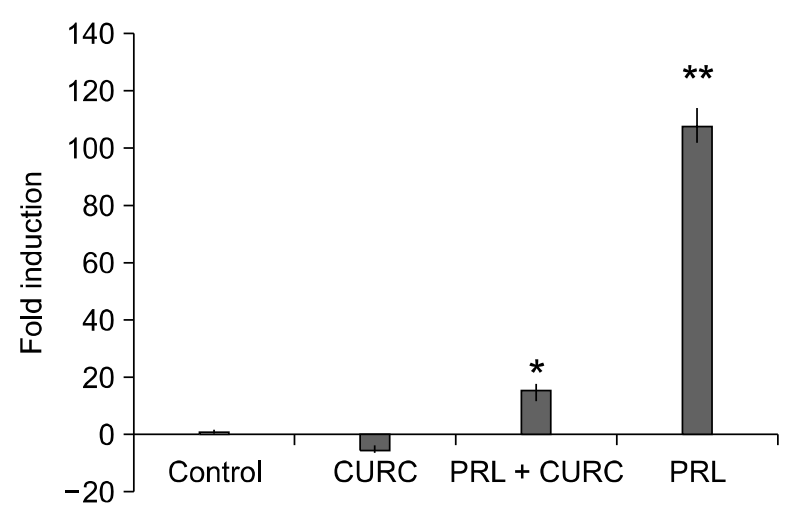

Figure 8. CURC inhibited, with or without prolactin, the expression of $\beta$-casein. $\mathrm{HC} 11$ cells were maintained under proliferative conditions, in the presence of $10 \mathrm{ng} / \mathrm{ml} \mathrm{EGF}$ and $5 \mu \mathrm{g} / \mathrm{ml}$ insulin to reach confluence and, then, incubated for $48 \mathrm{~h}$ in differentiation medium containing $1 \mu \mathrm{M}$ dexamethasone and $10 \mathrm{ng} / \mathrm{ml}$ insulin, CURC $(100 \mathrm{ng} / \mathrm{ml})$ and/or prolactin $(5 \mu \mathrm{g} / \mathrm{ml})$. Levels of $\beta$-casein mRNA were monitored by Real-Time PCR. Data are mean \pm SD of three independent experiments. * means $P<$ $0.05 ;$ ** means $P<0.001$.

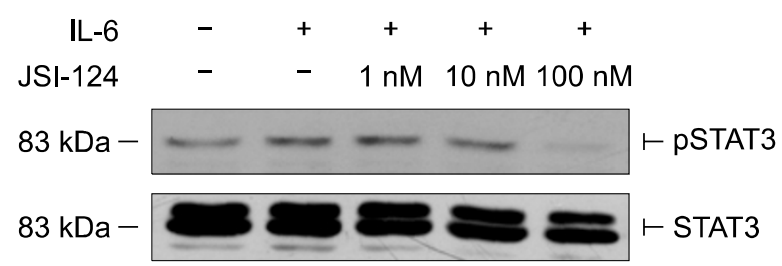

Figure 9. Effect of JSI-124 on the inhibition of STAT-3 phosphorilation. IL-6 was used as positive control to enhance p-STAT3. HC11 cells were starved overnight without FCS and incubated for $60 \mathrm{~min}$ with or without JSI-124 used in scalar concentrations, after that IL-6 (positive control for p-STAT-3) was incubated for $15 \mathrm{~min}$. Total STAT-3 was measured to normalize the samples. fluent HC11 cells, addition of CURC (100 ng) influenced significantly the induction of $\beta$-casein mRNA levels analysed by real time PCR (Figure 8).

\section{Specific inhibition of STAT-3 pathway reduced CURC effects on cell viability}

We used a specific JAK2/STAT-3 inhibitor to confirm that CURC affects STAT-3 pathway. In our model, JSI-124 was able to reduce the activation of p-STAT3 at $100 \mathrm{nM}$ (see Figure 9) when cells were treated with IL-6, used as positive control (Zhao et al., 2004). When JSI-124 was associated with CURC we observed a decrease in cleaved caspase-3 amount at 10 and $100 \mathrm{nM}$ (Figure 10). Finally, we repeat the experiment on the effect of CURC $(100 \mathrm{ng} / \mathrm{ml})$ on cell viability in presence of

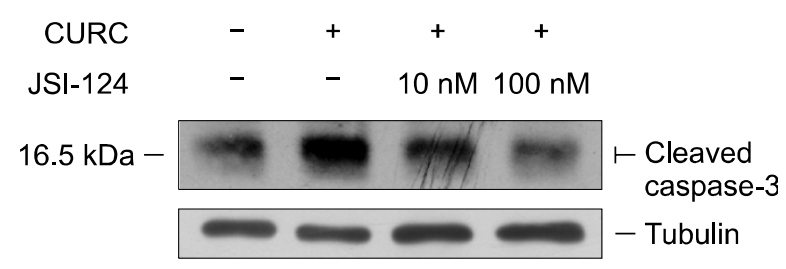

Figure 10. JSI-124 reduces CURC effect on cleaved caspase 3 assessed by Western blot: cells were incubated for $12 \mathrm{~h}$ in medium RPMl $1640,3 \%$ FCS containing CURC (100 ng/ml) alone or with JSI-124 (10 and $100 \mathrm{nM})$.

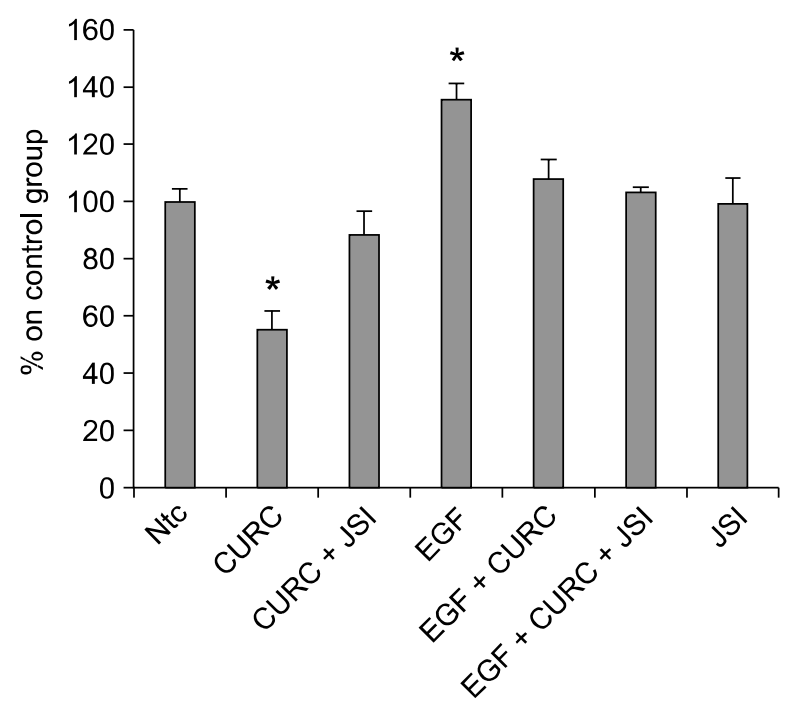

Figure 11. Effect of JSI-124 on HC11 cell viability in association with CURC. Cells were treated with CURC $(100 \mathrm{ng} / \mathrm{ml})$, JSI-124 $(100 \mathrm{nM})$, EGF $(10 \mathrm{ng} / \mathrm{ml})$, ntc (non-treated control). Cell viability was measured by WST-1 test. Data are expressed as percentage on internal control for each cell type measured after $12 \mathrm{~h}$ after cell seeding (time 0 ) and are mean \pm SEM of 8 replicated repeated in three independent experiments. The measurement of cell viability was performed after $24 \mathrm{~h}^{*}{ }^{*}$ mean $P<0.05$. 


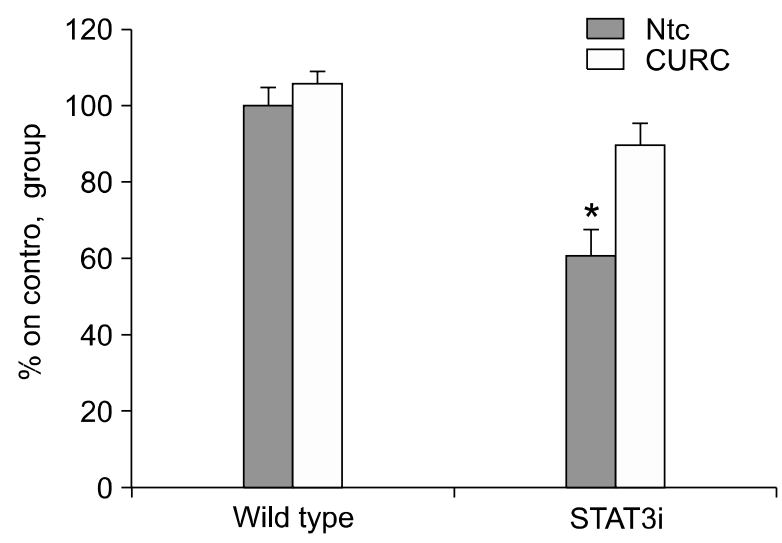

Figure 12. Effect of CURC in cell viability in wild type and STAT3 $3^{i} \mathrm{HC11}$ cell line. Cell viability was measured by WST-1 test. Data are expressed as percentage on internal control for each cell type measured after $12 \mathrm{~h}$ after cell seeding (time 0 ) and are mean \pm SEM of 8 replicated repeated in three independent experiments. The measurement of cell viability was performed after $24 \mathrm{~h}$. ${ }^{*}$ mean $P<0.05$.

JSI-124: after 24 h of incubation, JSI-124 (100 nM) restored CURC-reduced cell viability (Figure 11). The effect was observed in presence or absence of EGF, the major proliferative factor in this model.

\section{Specific ablation of STAT-3 reduces CURC effects on cell viability}

We stably infected $\mathrm{HC} 11$ cells with a lentiviral gene transfer vector encoding for STAT3 specific small hairpin RNA (shRNA) (STAT-3i HC11). We have previously demonstrated that the expression of the STAT-3 protein in this cell population is markedly reduced (Motta et al., 2007). Transfection of cells with a vector encoding a control, unrelated shRNA had no effect on STAT-3 expression. STAT-3 $3^{\text {H HC11 }}$ showed a significant resistance to CURC inhibitory effect on cell viablity compared to wild type cell (Figure 12). To investigate if STAT-3 downregulation reduced CURC effect on caspase activity, we repeated the experiment described in Figure 5: CURC did not significantly enchance caspase 3 activity from 0.1 to $10 \mathrm{ng} / \mathrm{ml}$ as in wild type cells, only at $100 \mathrm{ng} / \mathrm{ml}$ we observed an slightly but not significant increase (Figure 13).

\section{Discussion}

In this study, we report the effect of CURC in normal breast cell lines. We propose a mechanism of action of CURC to induce apoptosis in this model. We used mouse mammary cell line HC11 as a model to investigate if the STAT-3 pathway is involved in the biological effect of CURC during

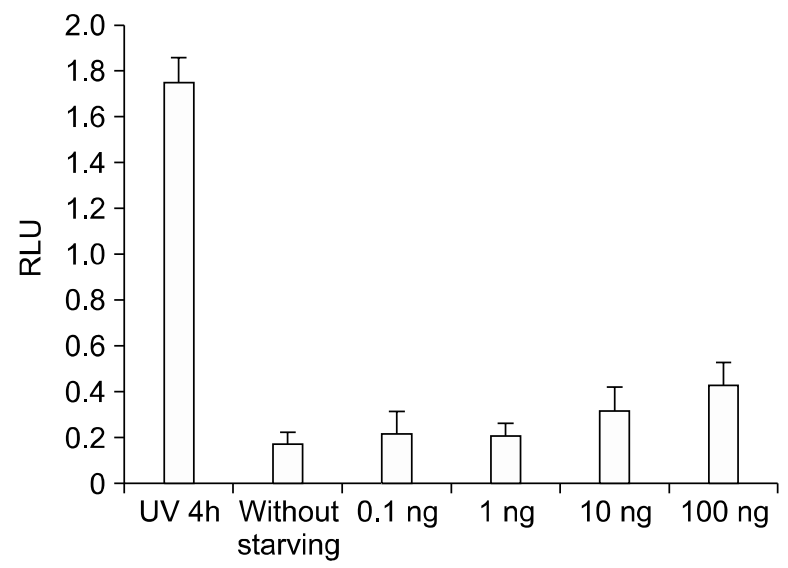

Figure 13. CURC effect on caspase activity measured by Caspase-3 Substrate II fluorogenic reaction in STAT- $3^{i}$ HC11 cells. Data were normalized on the control (not starved cell). Positive control was performed by a UV-treatment for $4 \mathrm{~h}$. Data are expressed as mean \pm SEM of 10 replicates, repeated three times.

differentiation and viability of mammary cells. These observations show a reduction in cell viability and an activation of apoptotic processes throughout specific activation of intracellular pathway (STAT-3 pathway) while no effects have been observed in differentiation regulation (STAT-5 pathway).

Recent studies have found that curcumin has a dose dependent chemopreventive effect in several animal tumor bioassay systems, including colon, duodenal, stomach, esophageal and oral carcinogenesis. However, it is not clear if this effect may be exerted only in tumor cells for their specific metabolism or it has a significant effect also in normal, not malignant cells. This point should be taken into account to avoid collateral effect during a chemopreventive therapy.

The molecular basis of anti-carcinogenic and chemopreventive effects of curcumin is attributed to its effect on several targets, including transcription factors, growth regulators, adhesion molecules, apoptotic genes, angiogenesis regulators and cellular signaling molecules (Aggarwal et al., 2003). Curcumin has been shown to down regulate the production of pro-inflammatory cytokines TNF- $\alpha$, $\mathrm{IL}-1 \beta$ and inhibit the activation of NF-KB and AP-1, which regulate the genes for pro-inflammatory mediators and protective antioxidant genes (Surh et al., 2000). The key regulators involved in apoptosis are well characterized and include caspases, $\mathrm{Bcl}-2$ family, TNF receptor family and other adapter proteins. Curcumin has been demonstrated to induce apoptosis in a variety of cells, including prostate cancer cells (Dorai et al., 2004). Curcumin treatment suppressed the constitutive activation of 
NFKB and AP-1 in DU145 cells and in turn down regulates endogenous bcl-2 and baxxL (Mukhopadhyay et al., 2001).

In this study, we investigated if curcuminoids are involved in the regulation of STATs family in the physiological remodelling of mammary gland during pregnancy and involution at the end of lactation. The HC11 cell line is considered a reliable model to study the role of factors and hormones involved in the growth and differentiation of mammary epithelial cells (Doppler et al., 1989). Since these cells retain the ability to express milk proteins if cultured to confluence and treated with the appropriate hormones, HC11 cells have been extensively used for the study of the regulation of milk protein gene expression by lactogenic hormones. A second mammary cell line was used to confirm the observations, BME-UV bovine mammary epithelial cell. During pregnancy, the expression and activity of the STAT family is variably modulated, with the expression and activity of STAT- 5 closely linked to the onset of lactation, whereas the expression and activity of STAT- 1 and -3 are associated with the virgin animal and involution (Chapman et al., 2000). In particular, STAT-3 mice with a conditional knockout of STAT-3 within the mammary gland demonstrate delayed mammary involution after cessation of pregnancy (Chapman et al., 1999). Thus, STAT-5 plays a critical role in lobuloalveolar differentiation, whereas STAT-3 regulates lobuloalveolar apoptosis during pregnancy, lactation and involution. In our model, STAT-3 ablation increased significantly cell viability with or without EGF association, that is considered the main mitogenic factor in $\mathrm{HC} 11$ cell line. In this contest, CURC reduced STAT-3 activation that functionally induced a reduction of cell viability. Recently, this effect was also reported in TNF- $\alpha$-stimulated human umbilical vein endothelial cells (Kim et al., 2007). We used a new selective inhibitor of Jak2/STAT-3 signaling to investigate if CURC acts on this pathway and cells treated with this inhibitor are not responsiveness to CURC negative effect on cell viability. Further, also in STAT-3' HC11 cells CURC was not able to negatively influence cell viability. The results of these two different approaches lead to assume that CURC effect STAT-3 pathway. Further, we showed that caspase- 3 amount has been increased by CURC treatment and that a quantitative relationship may be observed between CURC concentration and caspase activity.

MAPKs are among the central elements that transduce extracellular signaling into cellular responses, and are believed to play a pivotal roles in cell growth and survival (Seger and Krebs, 1995). AKT signaling pathway is also associated with cell motility and invasion (Zhou and Wong, 2006). CURC also slightly reduced MAPK and AKT activations. These pathways are activated by growth factors such as EGF and IGF-1 that, in our models, are known as essential as mitogenic and survival factors, and in many cases MAPK and AKT are upstream kinases for the activation of STAT-3. We would hypothesize that other pathways are involved in the regulation of STAT-3 activation. For istance, it has been recently reported some other factors that are involved in STAT-3 pathway: suppressor of cytokine signaling-1 (SOCS-1) has been implicated recently in the negative regulation of IL-6R/JAK mediated activation of STAT-3, suggesting that SOCS-1 could affect alternative activation of STAT 3 by EGFR and IL-6R (Lee et al., 2006).

Because the dysregulation of c-myc is associated with cellular proliferation, its downregulation has been linked with growth arrest of cancer cells. Several studies have reported the role of curcuminoids in the growth arrest of cancer cells in culture and in animal models (Huang et al., 1997). It has been reported that loss of c-myc could result in the arrest in G1-S phase of the cell cycle eventually leading to cell death (Dang et al., 2006). Instead curcuminoids induce growth arrest, mostly at the G2-M stage, thus, unlike other known chemotherapeutic compounds, curcuminoids do not cause any damage to the normal cells (Syng-Ai et al., 2004). In our study we propose that, at least in breast epithelium, a significant and specific effect of CURC has been observed in normal cells. This effect seems to be linked to growth factors and cytokines activation that normally are involved in mammary cell proliferation and differentiation. These results induce to investigate further its use as a valid chemopreventive and chemotherapeutic agent in malignancy. Knowledge acquired from this study will, therefore, lead us one step forward toward that goal.

\section{Acknowledgements}

This work was supported by a COFIN 2005 and $60 \%$ Università di Torino 2005.

\section{References}

Aggarwal BB, Kumar A, Bharti AC. Anticancer potential of curcumin: preclinical and clinical studies. Anticancer Res 2003;23:363-98

Baratta M, Grolli S, Poletti A, Ramoni R, Motta M, Tamanini C. Role of androgens in proliferation and differentiation of mouse mammary epithelial cell line HC11. J Endocrinol 2000;167:53-60 
Blaskovich MA, Sun J, Cantor A, Turkson J, Jove R, Sebti SM. Discovery of JSI-124 (cucurbitacin I), a selective Janus kinase/signal transducer and activator of transcription 3 signaling pathway inhibitor with potent antitumor activity against human and murine cancer cells in mice. Cancer Res 2003;63:1270-9

Chapman RS, Lourenco PC, Tonner E, Flint DJ, Selbert S, Takeda K, Akira S, Clarke AR, Watson CJ. Suppression of epithelial apoptosis and delayed mammary gland involution in mice with a conditional knockout of Stat3. Genes Dev 1999;13:2604-16

Chapman RS, Lourenco P, Tonner E, Flint D, Selbert S, Takeda K, Akira S, Clarke AR, Watson CJ. The role of Stat3 in apoptosis and mammary gland involution. Conditional deletion of Stat3. Adv Exp Med Biol 2000;480:129-38

Chatterjee M, Stuhmer T, Herrmann P, Bommert K, Dorken $B$, Bargou RC. Combined disruption of both the MEK/ERK and the IL-6R/STAT3 pathways is required to induce apoptosis of multiple myeloma cells in the presence of bone marrow stromal cells. Blood 2004;104:3712-21

Choudhuri T, Pal S, Agwarwal ML, Das T, Sa G. Curcumin induces apoptosis in human breast cancer cells through p53-dependent Bax induction. FEBS Lett 2002;512:334-40

Cohen JJ. Apoptosis. Immunol Today 1993;14:26-30

Dang CV, O'Donnell KA, Zeller KI, Nguyen T, Osthus RC, Li F. The c-Myc target gene network. Semin Cancer Biol 2006;16:253-64

Doppler W, Groner B, Ball RK. Prolactin and glucocorticoid hormones synergistically induce expression of transfected rat beta-casein gene promoter constructs in a mammary epithelial cell line. Proc Natl Acad Sci USA 1989;86:104-8

Dorai T, Dutcher JP, Dempster DW, Wiernik PH. Therapeutic potential of curcumin in prostate cancer--V: Interference with the osteomimetic properties of hormone refractory C4-2B prostate cancer cells. Prostate 2004;60:1-17

Follenzi A, Ailles LE, Bakovic S, Geuna M, Naldini L. Gene transfer by lentiviral vectors is limited by nuclear translocation and rescued by HIV-1 pol sequences. Nat Genet 2000;25:217-22

$\mathrm{He} X \mathrm{H}$, Lin LZ, Lian LZ, Lindenmaier M. Liquid cromatography-electrospray mass spectrometric analysis of curcuminoids and sesquiterpenoids in turmeric (Curcuma longa). J Cromatography A 1998;818:127-32

Hermisson M, Wagenknecht $B$, Wolburg $H$, Glaser $T$, Dichgans J, Weller M. Sensitization to CD95 ligand-induced apoptosis in human glioma cells by hyperthermia involves enhanced cytochrome c release. Oncogene 2000;19: 2338-45

Huang HC, Jan TR, Yeh SF. Inhibitory effect of curcumin, an anti-inflammatory agent, on vascular smooth muscle cell proliferation. Eur J Pharmacol 1992;221:381-4

Huang MT, Newmark HL, Frenkel K. Inhibitory effects of curcumin on tumorigenesis in mice. J Cell Biochem Suppl $1997 ; 27: 26-34$

Jiang MC, Yang-Yen HF, Yen JJ, Lin JK. Curcumin induces apoptosis in immortalized NIH 3T3 and malignant cancer cell lines Nutr Cancer 1996;26:111-20

Kim YS, Ahn Y, Hong MH, Joo SY, Kim KH, Sohn IS, Park HW, Hong YJ, Kim JH, Kim W, Jeong MH, Cho JG, Park JC, Kang JC. Curcumin attenuates inflammatory responses of TNFalpha-stimulated human endothelial cells. J Cardiovasc Pharmacol 2007;50:41-9

Korutla L, Kumar R. Inhibitory effect of curcumin on epidermal growth factor receptor kinase activity in A431 cells. Biochim Biophys Acta 1994;1224:597-600

Kuttan R, Bhanumathy P, Nirmala K, George MC. Potential anticancer activity of turmeric (Curcuma longa). Cancer Lett 1985;29:197-202

Lee TL, Yeh J, Van WC, Chen Z. Epigenetic modification of SOCS-1 differentially regulates STAT3 activation in response to interleukin- 6 receptor and epidermal growth factor receptor signaling through JAK and/or MEK in head and neck squamous cell carcinomas. Mol Cancer Ther 2006;5:8-19

Liu ZY, Wang ZG, Liu XJ, Tian HM, Surapol, Na DY, Zhang YF, Zhang W. Antitumor effect and apoptosis induction in human cancer cell lines by BRM-SJS. Ai Zheng 2004;23: $1386-9$

Livak KJ, Schmittgen TD. Analysis of relative gene expression data using real-time quantitative PCR and the 2(-Delta Delta C(T)) Method. Methods 2001;25:402-8

Maheshwari RK, Singh AK, Gaddipati J, Srimal RC. Multiple biological activities of curcumin: a short review. Life Sci 2006;78:2081-7

Marczylo TH, Verschoyle RD, Cooke DN, Morazzoni P, Steward WP, Gescher AJ. Comparison of systemic availability of curcumin with that of curcumin formulated with phosphatidylcholine. Cancer Chemother Pharmacol 2007; 60:171-7

Marte BM, Jeschke M, Graus-Porta D, Taverna D, Hofer P, Groner B, Yarden Y, Hynes NE. Neu differentiation factor/heregulin modulates growth and differentiation of HC11 mammary epithelial cells. Mol Endocrinol 1995;9: 14-23

Motta M, Accornero P, Taulli R, Bernabei P, Desrivieres S, Baratta M. Leptin enhances STAT-3 phosphorylation in HC11 cell line: effect on cell differentiation and cell viability. Mol Cell Endocrinol 2007;263:149-55

Mukhopadhyay A, Bueso-Ramos C, Chatterjee D, Pantazis $P$, Aggarwal BB. Curcumin downregulates cell survival mechanisms in human prostate cancer cell lines. Oncogene 2001;20:7597-09

Pan MH, Lin-Shiau SY, Lin JK. Comparative studies on the suppression of nitric oxide synthase by curcumin and its hydrogenated metabolites through down-regulation of IkappaB kinase and NFkappaB activation in macrophages. Biochem Pharmacol 2000;60:1665-76

Reddy S, Rishi AK, Xu H, Levi E, Sarkar FH, Majumdar AP. Mechanisms of curcumin- and EGF-receptor related protein (ERRP)-dependent growth inhibition of colon cancer cells. Nutr Cancer 2006;55:185-94 
Satoskar RR, Shah SJ, Shenoy SG. Evaluation of antiinflammatory property of curcumin (diferuloyl methane) in patients with postoperative inflammation. Int $\mathrm{J}$ Clin Pharmacol Ther Toxicol 1986;24:651-4

Seger R, Krebs EG. The MAPK signaling cascade. FASEB J 1995;9:726-35

Shibata MA, Maroulakou IG, Jorcyk CL, Gold LG, Ward JM, Green JE. p53-independent apoptosis during mammary tumor progression in C3(1)/SV40 large T antigen transgenic mice: suppression of apoptosis during the transition from preneoplasia to carcinoma. Cancer Res 1996;56:29983003

Sidhu GS, Mani H, Gaddipati JP, Singh AK, Seth P, Banaudha KK, Patnaik GK, Maheshwari RK. Curcumin enhances wound healing in streptozotocin induced diabetic rats and genetically diabetic mice. Wound. Repair Regen 1999;7: 362-74

Singh S, Aggarwal BB. Activation of transcription factor NF-kappa B is suppressed by curcumin (diferuloylmethane). J Biol Chem 1995;270:24995-5000

Surh YJ, Han SS, Keum YS, Seo HJ, Lee SS. Inhibitory effects of curcumin and capsaicin on phorbol ester-induced activation of eukaryotic transcription factors, NF-kappaB and
AP-1. Biofactors 2000;12:107-12

Syng-Ai C, Kumari AL, Khar A. Effect of curcumin on normal and tumor cells: role of glutathione and bcl-2. Mol Cancer Ther 2004;3:1101-8

Taulli R, Accornero P, Follenzi A, Mangano T, Morotti A, Scuoppo C, Forni PE, Bersani F, Crepaldi T, Chiarle R, Naldini $\mathrm{L}$, Ponzetto C. RNAi technology and lentiviral delivery as a powerful tool to suppress Tpr-Met-mediated tumorigenesis. Cancer Gene Ther 2005;12:456-63

Toda S, Miyase T, Arichi H, Tanizawa H, Takino Y. Natural antioxidants. III. Antioxidative components isolated from rhizome of Curcuma longa L. Chem Pharm Bull (Tokyo) 1985;33:1725-8.

Zhao L, Hart S, Cheng J, Melenhorst JJ, Bierie B, Ernst M, Stewart C, Schaper F, Heinrich PC, Ullrich A, Robinson GW, Hennighausen L. Mammary gland remodeling depends on gp130 signaling through Stat3 and MAPK. J Biol Chem 2004;279:44093-100

Zhou HY, Wong AS. Activation of p70S6K induces expression of matrix metalloproteinase 9 associated with hepatocyte growth factor-mediated invasion in human ovarian cancer cells. Endocrinology 2006;147:2557-66 